\title{
Does Paneloux Lose Faith? \\ Rethinking the Relationship Between \\ Belief and Action in Camus' The Plague
}

\author{
Tamela Ice \\ University of Kansas
}

Since belief is measured by action, he who forbids us to believe religion to be true necessarily also forbids us to act as we should if we did believe it be true.

William James'

Patrick Kiaran Dooley says that "[r]eligious philosophy is ... primarily concerned with the existence and nature of God and only secondarily with the difference belief in God makes in man's life." Dooley continues to explain that William James "is concerned with the nature and function of belief in God and the difference that belief makes." According to James, "religious philosophy considers three questions: the nature and legitimacy of belief; the effect of belief; and the existence and nature of the object of belief." 4 James deals with these questions separately in his various works.

Albert Camus is not interested in entering into a debate over the nature and existence of God. He is, however, very interested in the legitimacy and effect of belief in a particular concept of God (the traditional Christian concept). Camus agrees with James that "belief is measured by action,"s and belief is a choice. That is, we can know what we really believe, as well as what others really believe by considering whether our actions (or the actions of others) are consistent with our (their) belief claims. In The Myth of Sisyphus Camus repeatedly associates belief with action. In addition, Camus provides a method for choosing what we can legitimately believe (or what we will choose to believe, regardless of the logic behind the belief). Camus lays out exactly what is required of a belief if it really is a belief. For example, Camus says, "[i]t is probably true that a man remains forever unknown to us 
and that there is in him something irreducible that escapes us. But practically I know men and recognize them by their behavior, by the totality of their deeds, by the consequences caused in life by their presence."6

It is common to analyze the two sermons in Camus's novel The Plague from the perspective of what Dooley refers to as religious philosophy. We might just as easily call this a theological approach. From this point of view, the two sermons are interpreted as two (unsatisfactory) Christian responses to the problem of evil. The attempt is made to preserve the attributes (or nature) of God when faced with the reality of evil in the world. God's existence is assumed. Father Paneloux, the Jesuit priest who delivers the two sermons in the novel, is treated as the voice of the church. Insofar as Camus wanted The Plague to be read at many levels, there are numerous points of view we can take with regard to the two sermons and the role of Father Paneloux. In this paper, I will focus on how the sermons illustrate a particular Christian concept of God and the course of action prescribed by this God. I will consider Paneloux as an illustration of an individual who accepts the consequences of his beliefs about God. That is, Paneloux really does believe in the all-powerful, all-loving God he posits in his two sermons. Although there are some inconsistencies, I will argue that Paneloux's actions are, ultimately, consistent with his beliefs.

I will focus on a few specific details in Paneloux's two sermons. This will reveal what Paneloux believes and the course of action prescribed. This will also bring to light the challenge for the Christian - is this a God Paneloux can believe in? Finally, I will look at how Paneloux's actions appear inconsistent, from Rieux's point of view, but ultimately agree with his beliefs.

II

The principle can be established that for a man who does not cheat, what he believes to be true must determine his action.

Albert Camus?

For Camus, the important beliefs are those which "determine my relationship with life." Whether our relationship to life is deter- 
mined by the absurd, God, or law, "I must sacrifice everything to these certainties and I must see them squarely to be able to maintain them. Above all, I must adapt my behavior to them and pursue them in all their consequences." This issue is brought to light in The Plague with Rieux's and Tarrou's responses to Paneloux's two sermons. The question is "whether or not one can live with one's passions, whether or not one can accept their law."10 For Paneloux, the certainty, the Absolute that determines his relationship with life, is an all-powerful, all-loving God. As will be shown, Rieux does not think Paneloux can live with the law of God.

Our primary source of information about Paneloux comes from Rieux and Tarrou, two rebels who disagree as to whether Paneloux really believes in the God he posits in his two sermons. After the first sermon, Rieux records in the "chronicle" that "if he believed in an all-powerful God, he would cease curing the sick, leaving that concern to Him [God]. But no one, no, not even Paneloux, who believed that he believed in it, believed in a God of this sort, since no one gave himself up completely." The relationship between belief and action is clear, and it holds for Tarrou as well. Following Paneloux's second sermon, Rieux recounts (to Tarrou) Paneloux's words on what to do (the appropriate course of action to be taken) in the face of the death of an innocent child. Tarrou responds by relating a story of a priest who lost his faith during the war when he saw a young boy with his eyes punctured (poked out). With regard to the priest, Tarrou says Paneloux "is right ... . when the innocent have had their eyes punctured, a Christian must lose faith or agree to have his eyes punctured. Paneloux does not want to lose faith, he will go to the end. That is what he meant."12 For both Rieux and Tarrou, if Paneloux really believes in the God he posits, his actions will be consistent with his beliefs.

What do we know about Paneloux? We first meet Paneloux in April, when he is assisting a parishioner (Michel) who is exhibiting symptoms of the plague. We are informed that Paneloux is a learned and "militant" Jesuit priest. We can understand "militant" as an "ardent defender of a demanding Christianity."13 Rieux had met Paneloux from time to time, but the two are not close friends. Paneloux is held in high regard by the citizens of Oran, "even among those indifferent to matters of religion."14 In this scene, after Michel 
is sent home, Rieux asks Paneloux what he thinks of the story of the rats. Paneloux says "it must be an epidemic."15 It has been suggested that Paneloux "makes the first correct assessment of the situation in Oran ... Paneloux is aware of the concrete situation around him."16 I disagree with this claim. The narrator (whom we know is Rieux) stresses that at this time, people were not overly concerned with the situation. Paneloux does not have great insight into the situation. He is, after all, talking about the rats. He does not indicate that he sees this epidemic as problematic for the people of Oran. He says nothing about Michel's illness. It is important to bear in mind that this is Rieux's account of Paneloux's reaction to the situation in the early stages. After Paneloux's response, the narrator tells us that "his eyes smiled behind round glasses."17 Glasses clarify, bring into focus. They also distort things. As will be seen, Rieux is of the opinion that Paneloux's vision is distorted. No one, not even Paneloux, sees the situation clearly.

Our next meeting with Paneloux is in May, immediately prior to his first sermon. The church authorities in Oran decided to fight against the plague with their own particular methods by organizing a week of collective prayer. Paneloux is asked to deliver a sermon at the end of this week of prayer.

Again, Rieux tells us something about Paneloux. In addition to what we already know, we learn that Paneloux "was already distinguished by frequent collaborations on reports for the Geographical Society of Oran." ${ }^{\prime 18} \mathrm{He}$ is recognized as an authority on interpreting ancient texts. Paneloux has presented papers on modern individualism at several conferences. As an ardent defender of Christianity, Paneloux is equally removed from modern libertinage and obscurantism of past centuries. Paneloux has a reputation as a forthright man who states hard truths as he sees them. It is important to note that Paneloux is a scholar. His domain is not dealing with the sick and dying. Nor is his domain behind the pulpit.

Paneloux is an enthusiastic and passionate defender of God and Christianity. He accepts with resolution the mission he is given. It is interesting to note that Paneloux thinks of his first sermon as a "mission." Paneloux spends fifteen days preparing for this sermon, putting aside his work on Augustine and the African Church. 
There are distinct differences between the two sermons: the congregation, the climate, the style of presentation, Paneloux's use of pronouns, the question of knowledge of God's will (and His reasons for willing what he does), and, importantly, the source, or the person who witnesses and records the sermons. There are also important similarities, which I will discuss after pointing out important points in the second sermon.

On the day of the first sermon, the church is filled with both men and women. Some people must find space on the staircase or in the square in front of the church. The narrator stresses that this is not typical. In "normal" times, before the plague, on Sunday mornings the sea was serious competition for mass. For Camus, the sea is the standard symbol for freedom. In The Myth of Sisyphus Camus says, "[t]he only conception of freedom . . . I know is freedom of thought and action."19 The citizens of Oran are prisoners in a sense, locked inside the city. From Rieux's perspective, we can think of Paneloux as a prisoner of his own beliefs. Oran is built in such a way that the city faces away from the sea. One must go in search of the sea (freedom). Thus, not being allowed to go to the sea, the people of Oran go to mass. We have less information about the elements in and around the second sermon. However, we do know that only men are present at this sermon, and Rieux is one of those men.

The next difference to be discussed is the style of presentation. At the first sermon, Paneloux's presentation style is forceful and passionate. He is certain of his claims. The second sermon follows on the heels of the excruciating death of Philippe (typically referred to as "the child"). Rieux records in the chronicle that after witnessing Philippe's death, Paneloux seemed to have changed. ${ }^{20}$ We do get the impression of a much more subdued, less certain man in the second sermon.

During the first sermon it is raining so loudly that it threatens to drown out Paneloux's words. After the sermon, the rain stops and wind takes over. During the second sermon, it is the wind that competes with Paneloux, followed by wet sidewalks and the smell of rain in the air. This is a reversal in climate. Rieux expects a reversal in Paneloux's beliefs about God and the appropriate course of action in times of plague. ${ }^{21}$ 
The narrator (Rieux) brings the reader's atteention to Paneloux's shift in pronoun use in the two sermons. The focus is on Paneloux's shift from "you" to "we." It is often claimed that in using "you" in the first sermon, Paneloux distances himself from the people of Oran. Clearly, Paneloux exempts himself from blame. Moreover, Paneloux is of the opinion that he knows the truth, and he can lead the people of Oran to that truth. However, Paneloux does not completely alienate himself from the community. In the first sermon Paneloux says " $m y$ brethren . . . you deserved it . . . we are in the darkness of the plague." 22

Another difference in the two sermons concerns knowledge of God's will. In the first sermon, Paneloux says we can know what God wills and why he wills it. Paneloux justifies divine evil by pointing the finger at the citizens of Oran (in the first sermon) and saying that God had good reasons for sending the plague (both sermons). The citizens of Oran brought this on themselves, according to the first sermon, by ignoring God. In the second sermon, Paneloux says we cannot always know God's will. Thus, in reference to the difference in pronoun use, dropping "you" indicates that Paneloux no longer claims to understand why God sent the plague to Oran. The citizens of Oran must simply accept that it is ultimately for some good. If we cannot know why God sent the plague, we cannot, with certainty, attribute blame.

Finally (and this is not an exhaustive list), it has been suggested that Rieux attended both sermons and it is his account the reader is given. ${ }^{23}$ There is no textual support for this claim. It does not seem likely that Rieux would be in attendance at the first sermon. The plague has spread at this point. Rieux is extremely dedicated to his profession, thus he would be attending the sick and dying. Moreover, Rieux has no particular interest in God or sermons at this time. In addition, the style in which the first sermon is recorded is inconsistent with Rieux's narrative style. It is, however, consistent with Tarrou's journal entries. Prior to an account of the first sermon, Rieux is citing information from Tarrou's journal. It is Tarrou who has a curiosity about what people are saying and doing. He records minute details, writing every word spoken. The first sermon is quoted, and the writing style is clearly that of Tarrou. Paneloux invites Rieux to attend the second sermon. Thus, we 
know Rieux was in attendance at the second sermon. Since Rieux relates the content of this sermon to Tarrou, we can assume that Tarrou was not in attendance at this sermon. The second sermon is recorded, with few direct quotes. The narrative is an overview of bits and pieces of the sermon. This raises an interesting point. In the disagreement over Paneloux's belief in an all-powerful God, Rieux is responding to the first sermon-the sermon recorded by Tarrou. Tarrou is responding to Rieux's account of the second sermon. This shifts our focus slightly when we read the two sermons. We know the opinion of the sources and that influences how the sermons, and Paneloux, are presented to the reader. This also allows the reader to enter into the dialogue by looking at Paneloux from both perspectives. The reader's own belief claims are challenged.

Thus far I have provided a brief description of Paneloux as a priest. We know what to expect in the first sermon. I have explicated some key differences in the two sermons. Thus, we expect to see changes in Paneloux. The cause of the change is his exposure to death, witnessing the death of Philippe (an innocent child). I will now turn to some important elements in the first sermon that, from Rieux's point of view, should challenge Paneloux's belief claims.

\section{III}

It is essential to consider as a constant point of reference... the regular hiatus between what we fancy we know and what we really know, practical assent and simulated ignorance which allows us to live with ideas which, if we truly put them to the test, ought to upset our whole life. ${ }^{24}$

Paneloux begins the first sermon with a dramatic opening: "My brethren, you are in misfortune, my brethren you deserved it."25 The term "misfortune" is the general translation for the French term "malheur." If we trace "misfortune" far enough, we find the term defined as "trial" or "tribulation." The people of Oran are on trial or in the midst of tribulation. This is a valid understanding of the term if we keep in mind that Paneloux immediately moves to a 
quotation from the Bible. Interestingly, this quotation is omitted and only summarized. Paneloux explains that historically, plague was first sent to "strike the enemies of God ... Since the beginning of history, God's plague has put the proud and the blind at His [God's] feet." 26 Paneloux encourages the congregation to "[m]editate on this, and fall to your knees."27

Eric Berg locates this scriptural passage as Exodus 4:21. Berg says Pharaoh did not "set himself up against God, it seems that he was set up against and by God. Is this a mistake by Camus or Paneloux? I blame the former." 28 This would not be the passage to cite if one is determined to defend an all-powerful, all-loving God. However, this is not a mistake. For Paneloux, Pharaoh brought the plague on himself by disobeying God. This is a lesson, and a warning, for the people of Oran. It is unknown to us whether Paneloux thought about the subsequent passages. Paneloux will argue that the people of Oran must reconcile themselves with God. In addition to establishing God in history (we know Paneloux is talking about the God of the Old Testament), what purpose does this reference to scripture serve? For Camus/Rieux, what is not said brings to light a challenge for Paneloux. This refers to the method of determining what we can believe-we must look at our certainties squarely and derive all the consequences. I will quote verses 21-23:

And the Lord said unto Moses, When thou goest to return into Egypt, see that thou do all those wonders before Pharaoh which I have put in thine hand: but I will harden his heart, that he shall not let the people go.

And thou shalt say unto Pharaoh, Thus saith the Lord, "Israel is my son, even my firstborn:

And I say unto thee, Let my son go, that he may serve me: and if thou refuse to let him go, behold, I will slay thy son, even thy firstborn. ${ }^{29}$

This is the God of Abraham and Isaac. God tested Abraham's faith by commanding the sacrifice of Isaac, Abraham's son. God is ready and able to slay Pharaoh's son. For Abraham, this is a test of faith. For Pharaoh, it is a test of obedience. The implication is that an allpowerful, all-loving God is also one who wills, and engages in, evil. 
This biblical reference takes on greater significance when we put it alongside the death of Philippe and the reference to Christ on the cross in the second sermon. I will return to this latter point later in this paper. Recall that Rieux is of the opinion that no one, not even Paneloux, really believes in this concept of God. Othon, the judge and Philippe's father, provides an example. Othon says that Paneloux's first sermon is "absolutely irrefutable." 30 As a judge, Othon supports the death penalty. People are put to death because they deserve it. Does Othon really believe this? When Philippe is taken to the hospital, Othon says "we must do what is prescribed." 31 Rieux records that Othon said "there was only one rule for all and that it was right to obey." ${ }^{23}$ It certainly seems that Othon accepts the absolute law of God, and the human law. However, in the midst of these comments, when Philippe is first taken to the hospital, Othon says "save my child." 33 From Rieux's perspective, this plea is inconsistent with the belief claims about God and Law. It is beyond the scope of this paper to fully examine Othon's actions as they relate to his belief claims. The point I want to stress is that the biblical reference can be understood as, not a mistake, but important in bringing to light exactly what one claims to believe, and the implications of that belief. If Othon really believes in the God Paneloux posits, he must accept the death of his own son without appeal. Moreover, he must accept that his son, somehow, deserved this suffering. This is also what Paneloux must accept.

The biblical reference is not a mistake if we look at the sermons as presenting what Rieux thinks is an important challenge for faith, or, what Tarrou thinks is an implication of faith that the "true" believer accepts-divine evil. We can wonder why the passages relating to God's willingness to kill children are omitted. Perhaps Camus thought the reader would be familiar with this passage, or curious enough to look it up. I suggest that omitting the verses is the point-one must look closely at what one claims to believe.

Paneloux goes on, in this first sermon, to say that the moment of reflection has come. The plague will separate the just from the unjust-which suggests that those who are afflicted with the plague are unjust. Again, we can think of what this means for Paneloux and Othon with regard to Philippe. ${ }^{34}$ Paneloux says that God did not want this plague, but it was necessary. The plague is no acci- 
dent of nature. For too long, Paneloux claims, this world, composed of evil, relied on divine mercy. It was considered easier to let evil reign-divine mercy would intervene. However, God grew weary of waiting for the people of Oran and He diverted his gaze. "Deprived of the light of God, we are here, for a long time, in the darkness of the plague!"35

Paneloux says that the people of Oran believed it would be enough to visit God on Sunday, keeping the rest of the week free. "You" thought that some genuflexions would suffice as payment for "your" criminal indifference. But, God is not luke-warm. These intermittent meetings with God did not satisfy God's devouring tenderness. God wanted to see the people of Oran more often, this is God's manner of loving. Paneloux says that, "to tell the truth, it is His only manner of loving. ${ }^{36}$ For this reason, tired of waiting for their arrival, God let the plague visit the people of Oran as it visited "all the cities of sin since the beginning of [human history]." Paneloux says that the people of Oran know what their sin is, "just as Cain knew it, and his sons, those before the flood, those of Sodom and Gomorra, Pharaoh and Job, and all the unjust." ${ }^{\text {"38 And, }}$ as in these cases, the people now have a fresh view of what is going on-now they know why God sent the plague. The people know now, and finally, that it is necessary to get to the core of the matter-the course of action required.

Paneloux says that his reason for delivering this sermon is that "I want you to come to the truth and learn how to be delighted, despite everything I said ... Today the truth is a command ... finally the divine mercy appears which puts into anything good and evil, anger and pity, the plague and safety. This plague, which you deserve, raises you and shows you the way." ${ }^{39}$

Paneloux cautions against suicide as a course of action in the face of the plague. One must not hurry the hand of God. The suffering of individual's afflicted with the plague reveals the "exquisite gleam of eternity-which lies at the bottom of any suffering." ${ }^{40}$ The lesson to be learned is that this suffering expresses the divine will, which, without failure, transforms evil into good. Paneloux offers the citizens of Oran some consolation for his words that punish-he also offers a verb that alleviates-the only word which was Christian-love. "God will take care of the rest." 
Paneloux is hopeful that the citizens of Oran will offer this word to God. The people are not being advised to pray for mercy. Nor are they encouraged to assist the sick and dying. They are encouraged to make verbal amends to God for their crime against Him. Paneloux's concept of God and the course of action prescribed are clear. I will now look at elements in and around Paneloux's second sermon.

Paneloux's first sermon is delivered in May, in the early stages of the plague. The second sermon is delivered in October, after months of death. As I stated earlier, rain dominates during the first sermon, wind dominates during the second sermon. I have noted key differences between the two sermons. Now, I will explicate the content of the second sermon.

Paneloux has invited Rieux to attend this sermon. Paneloux has been working on an essay where he asks whether a priest should consult a physician. We will see that Paneloux is of the opinion that Rieux was wrong in treating Philippe with an experimental serum, and he does not think a priest should consult a physician. It is in this sermon and Paneloux's subsequent actions that we see the consistency between his beliefs and actions.

This sermon, as stated earlier, is primarily reported (summarized), not quoted. Although the congregation is smaller, Rieux is distracted and does not catch everything Paneloux says. Rieux thinks, however, that Paneloux is close to heresy.

Paneloux begins his sermon by saying that now, "we" have a clearer idea of what the plague should tell us, what it means. Paneloux says that explaining the reason for the plague is not the issue. What is needed is to learn from it. With regard to God, there are things that can be explained, and things that cannot be explained. There is good and evil, and in general, it is easy to explain what distinguishes between the two. It is within evil that difficulty arises. There is apparently necessary evil, and there is apparently useless evil. There is plunging Don Juan, the libertine, into Hell, and there is the suffering of a child. There is nothing more horrifying than the suffering of a child. Paneloux cannot say that there is compensation for a child's suffering (he cannot offer the compensation of an eternity of joy). "Who could affirm indeed that an eternity of joy could compensate for one moment of human pain?"42 
According to the first sermon, God wanted more from the people of Oran. In the second sermon, Paneloux says it is All or Nothing. It is necessary to believe all or to deny all. Paneloux asks, "who among you would dare to deny everything?"43 This injunction to believe all is, Paneloux says, the benefit and the virtue of Christianity. However, the religion in times of plague cannot be the religion of the everyday, and if God could wish that the heart rests and is delighted in times of happiness, he wants that in times of misfortune as well. This plague is the opportunity for the people to assume the greatest virtue-giving All to God.

Paneloux talks about the virtue of total acceptance, which is not resignation, but an agreement between mortification and humbleness. The suffering child is mortifying for the spirit and the heart. This is why is it necessary to accept this suffering because God willed it. The Christian can, and should, give himself up to the incomprehensible divine will. The Christian cannot say "I understand it but I do not accept it." It is necessary to leap into the heart of the unacceptable. The suffering of children is our bitter bread, but without this suffering, our heart would perish of its spiritual hunger. ${ }^{44}$

Paneloux tells the congregation of the appropriate action to be taken. Referring back to his first sermon, and the Christians of history who rolled themselves in the bedding of plague victims so they too would be afflicted, Paneloux says that one should not imitate them (one should not go to extreme lengths to expose oneself to plague-one should not rush the hand of God). Nor should one imitate the monks who isolated themselves and avoided all contact with plague victims. In both cases, the Christians remained deaf to God. But, Paneloux says, it is not a question of refusing precautions. It was not necessary to fall to one's knees and abandon hope. It was only necessary to move ahead in the darkness, somewhat blinded, and try to do some good. Other than that, it is necessary to rely on God (God will see to the rest), even for the death of children. ${ }^{45}$

Paneloux explains that the love of God is a difficult love. It assumes the total abandonment of oneself. But only God can erase the suffering and death of children, only God can make this suffering necessary. It is impossible to understand it, one can only want 
it, because God wants it. "Here is faith, cruel in the eyes of men, decisive in the eyes of God, whom it is necessary to approach." ${ }^{.46}$

The God of the first sermon is the God of the Old Testament. In the second sermon, Paneloux refers to the New Testament by comparing the suffering of the "earthly" father at the death of his child with God's suffering at the death of Christ. Paneloux says that the cross is the symbol, face to face, with the suffering child. After watching Philippe writhe in pain, Rieux describes his body as "a grotesque parody of crucifixion." ${ }^{\text {47 }}$ If we accept the divinity of Christ, which Paneloux does, we can think of the reference to Pharaoh's son, the death of Othon's son, and the death of ChristGod's son. Christ, in his ninth hour on the cross cried out to his father, "My God, my God, why has thou forsaken me?" God does not respond-He diverts His gaze. This is another consequence of belief, if we agree with Camus that belief prescribes action. One must not, according to Paneloux, interfere with God's will. One must accept it-one must not stay the hand of God.

As far as the content is concerned, very little changes in the two sermons. In both sermons, Paneloux stresses that there is some benefit in the evil that is visited on Oran. This "truth" is held firmly in both sermons. In both sermons, Paneloux focuses on what is owed to God. Paneloux still makes a plea for acceptance. In the first sermon, Paneloux says the citizens of Oran must accept responsibility for their behavior. They must also accept that the plague is God's will. In the second sermon, the people are encouraged again to accept God's will, and to give God All.

Paneloux's concept of God has not changed between the two sermons. He has modified his views regarding the appropriate course of action. According to the first sermon, the citizens of Oran are not encouraged to act in order to relieve suffering or end the plague. In the second sermon, the people are encouraged to act only insofar as their actions do not interfere with the will of God. Paneloux's opinion that we can know the will of God changes. Paneloux is affected by his exposure to suffering and death. However, God remains the same and Paneloux's actions are based on his beliefs about God.

I will look at some of Paneloux's actions throughout the novel to support Tarrou's claim that he does believe in the God posited in 
the two sermons. I will also address certain apparent inconsistencies between what Paneloux claims to believe and his actions.

Some of the inconsistencies between what Paneloux believes about God and the action prescribed by those beliefs and his actual actions may lead us to agree with Rieux's claim that no one really believes in the God of Paneloux's two sermons. Rieux certainly expects exposure to suffering and death to change Paneloux's mind on this issue. For example, when we first meet Paneloux, he is assisting Michel, the parishioner afflicted with plague. This seems to go against what Paneloux recommends as a course of action in the first sermon. However, if we look closely at the text, Michel says that he was "obliged to return and ask Father Paneloux for assistance." ${ }^{48}$ Paneloux, knowing that Michel is ill, does not offer to assist him to his home. This seems to be consistent with the course of action prescribed in the second sermon. Paneloux is not doing more than is necessary.

We are also informed that Paneloux joins the sanitation workers. Indeed, Paneloux continues to work after his second sermon. Rieux will of course see this as inconsistent. Again, looking closely at the text, Tarrou says that he asked Paneloux to join the sanitation workers. Rieux asks what he said. Tarrou says, "he said he had to think about it, then he agreed."49 Rieux says "I am glad to know he is better than his sermon." 50 This conversation takes place after the first sermon, and Rieux thinks Paneloux's agreement to join the sanitation workers shows he does not really believe in the God of his sermon. However, Paneloux does hesitate. We do not know the specific details of Paneloux's "job". If Philippe's death scene is any indication, Paneloux's task, as he sees it, is to sit at the bedside of the afflicted and pray. Again, if we take the second sermon as Paneloux's final word on God and the appropriate course of action to take, the fact that he joins the sanitation workers is not inconsistent with his belief claims.

There is one point that raises the question of inconsistency. As they witness the death of Philippe, Paneloux pleads with God to "save this child." Ho However, in the end, Paneloux criticizes Rieux for using the serum to save Paneloux's life-it merely prolonged his suffering. Moreover, this interfered with God's will. We must not 
stay the hand of God. Ultimately, this too is consistent with Paneloux's second sermon.

In The Rebel, Camus says that "only two possible worlds can exist for the human mind: the sacred (or, to speak in Christian terms, the world of grace) and the world of rebellion." 52 After Philippe's death, Paneloux tells Rieux that perhaps we should love what we do not understand. Rieux rejects this kind of love, claiming that Paneloux knows this child is innocent. Rieux expects something very different in the second sermon. However, prior to this sermon Paneloux says he finally thinks he knows what "grace" means. Paneloux makes his choice at this moment-he chooses the world of grace/faith.

After his second sermon, two priests discuss the content of the sermon. A younger priest asks an older priest what Paneloux's point was. The older priest says that the point was, "if a priest consults a physician, there is a contradiction." 53 Shortly after this second sermon, Paneloux falls ill and refuses to allow a doctor to be called in. When he is too weak to protest, Rieux takes him to the hospital, and offers to stay with him. Paneloux says that a monk/ priest cannot have friends, he gives everything to God. All Paneloux asks for is his crucifix-he remains silent until the end.

My objective in this paper has been to show how Paneloux and his two sermons illustrate Camus's interest in the relationship between belief and action, and his method for deciding what one will believe. This method has been illustrated by looking closely at what Paneloux must accept, and the course of action prescribed. There is the question of Paneloux's death. Rieux records the priest's death as a "doubtful case." From a medical standpoint, Paneloux's death is doubtful because it is not certain that he died of the plague. Some of his symptoms are consistent with the plague, some are not. It does not appear that Paneloux doubts what he claims to believe. Paneloux does not lose his faith. Aside from the medical assessment, why is Paneloux a doubtful case? It seems that Rieux is the one who doubts. He doubts that anyone, including Paneloux, really believes in an all-powerful God. He doubts that Paneloux would believe in the God he posits if he closely examined the implications. This may be an unresolved question. The important point for this paper is the importance Camus places on looking at what 
difference it makes, to oneself and to others, if one believes in this particular concept of God. Clearly Paneloux accepts the consequences of his beliefs. What we can take from this is the method for choosing our beliefs. We have the means of knowing what we, or others, really believe, and why that matters.

\section{Notes}

' James, William. "The Will to Believe," in The Will to Believe and other essays in popular philosophy. New York: Dover Publications, Inc., 1956, p. 29, footnote 1.

\section{${ }^{2}$ Dooley, Patrick Kiaran.}

Pragmatism as humanism: The philosophy of William James. New Jersey: Littlefield, Adams \& Co., 1975, p. 82.

${ }^{3}$ Ibid.

${ }^{4}$ Ibid.

${ }^{5}$ James, p. 29, footnote 1.

${ }^{6}$ Camus, Albert. The Myth of Sisyphus and other essays. Translated from the French by Justin O'Brien. New York: Vintage International, 1983, p. 11.

${ }^{7}$ Camus, Myth, p. 6.

${ }^{8}$ Camus, Myth, p. 21.

${ }^{9}$ Ibid., p. 21-22.

${ }^{10} \mathrm{Ibid} ., \mathrm{p} .22$.

"Camus, Albert. La Peste (The Plague). Paris: Gallimard, 1947, p. 120. All translations from La Peste are my own.

${ }^{12}$ Ibid., p. 208.

${ }^{13}$ Camus, La Peste, p. 89.

${ }^{14}$ Ibid., p. 23.

${ }^{15}$ Ibid.

${ }^{16}$ Berg, Eric. "Paneloux's Turn: An Analysis of the Sermons of The Plague with Suggestion," unpublished, p. 1-2.

${ }^{17}$ Ibid.

${ }^{18}$ Ibid., p. 89.

${ }^{19}$ Camus, Myth, p. 56.

${ }^{20}$ Camus, La Peste, p. 200.

${ }^{21}$ Camus's sense of the divine is nature. Thus, we can see two concepts of the divine at work in the novel.

${ }^{22}$ Camus, La Peste, p. 91-92.

${ }^{23}$ Berg, p. 6.

${ }^{24}$ Camus, Myth, p. 18. 
${ }^{25}$ Camus, La Peste, p. 91.

${ }^{26} \mathrm{Ibid} .$, p. 92.

${ }^{27}$ Ibid.

${ }^{28}$ Berg, p. 12.

${ }^{29}$ The Holy Bible, Containing the Old and New Testaments. Translated out of the original tongues: and with the former translation diligently compared and revised, by His Majesty's special command. New York: Thomas Nelson \& Sons, publication date unknown, p. 60-61.

${ }^{30}$ Cams, La Peste, p. 96.

${ }^{31}$ Ibid., p. 193.

32 Ibid.

${ }^{33} \mathrm{Ibid}$.

${ }^{34}$ We can see another example of a priest and the death of a child in the second of Camus's "Letters to a German Friend."

${ }^{35}$ Camus, La Peste, p. 92.

${ }^{36}$ Ibid., p. 93.

${ }^{37}$ Ibid.

${ }^{38}$ Ibid.

${ }^{39}$ Ibid., p. 94.

${ }^{40}$ Ibid.

${ }^{41}$ Ibid., p. 95.

42 Ibid., p. 203.

${ }^{43}$ Ibid., p. 204.

${ }^{44}$ Ibid., p. 204-205.

${ }^{45}$ Ibid., p. 206.

${ }^{46}$ Ibid.

${ }^{47}$ Ibid., p. 195.

${ }^{48}$ Ibid., p. 23.

${ }^{49}$ Ibid., p. 140.

${ }^{50}$ Ibid.

${ }^{51}$ Ibid., p. 197.

${ }^{52}$ Camus, Albert. The Rebel. Translated from the French by Anthony Bower. New York: Vintage Books, 1991, p. 21.

${ }^{53}$ Camus, La Peste, p. 207. 